Research article Open Access

\title{
Enrichment methods to detect bone marrow micrometastases in breast carcinoma patients: clinical relevance
}

\author{
Valérie Choesmel ${ }^{1}$, Jean-Yves Pierga ${ }^{2}$, Claude $\mathrm{Nos}^{3}$, Anne Vincent-Salomon ${ }^{4}$, Brigitte Sigal- \\ Zafrani ${ }^{4,5}$, Jean-Paul Thiery ${ }^{1}$ and Nathalie Blin ${ }^{1}$
}

\author{
1UMR144 CNRS, Research Division, Institut Curie, Paris, France \\ 2Medical Oncology Department, Medical Division, Institut Curie, Paris, France \\ ${ }^{3}$ Surgery Department, Medical Division, Institut Curie, Paris, France \\ ${ }^{4}$ Tumor Biology Department, Medical Division, Institut Curie, Paris, France \\ ${ }^{5} \mathrm{On}$ behalf of the Institut Curie Breast Cancer Group \\ Corresponding author: Nathalie Blin, nathalie.blin@curie.fr
}

Received: 26 Feb 2004 Revisions requested: 10 May 2004 Revisions received: 14 May 2004 Accepted: 25 May 2004 Published: 29 Jul 2004

Breast Cancer Res 2004, 6:R556-R569 (DOI 10.1186/bcr898)

(C) 2004 Choesmel et al.; licensee BioMed Central Ltd. This is an Open Access article: verbatim copying and redistribution of this article are permitted in all media for any purpose, provided this notice is preserved along with the article's original URL.

\begin{abstract}
Introduction Improving technologies for the detection and purification of bone marrow (BM) micrometastatic cells in breast cancer patients should lead to earlier prognosis of the risk of relapse and should make it possible to design more appropriate therapies. The technique used has to overcome the challenges resulting from the small number of target cells (one per million hematopoietic cells) and the heterogeneous expression of micrometastatic cell markers. In the present study, we have assessed the clinical relevance of current methods aimed at detecting rare disseminated carcinoma cells.
\end{abstract}

Methods BM aspirates from 32 carcinoma patients were screened for the presence of micrometastatic cells positive for epithelial cell adhesion molecule and positive for cytokeratins, using optimized immunodetection methods. A comparison with data obtained for 46 control BM aspirates and a correlation with the clinical status of patients were performed.

Results We developed a sensitive and efficient immunomagnetic protocol for the enrichment of BM micrometastases. This method was used to divide 32 breast carcinoma patients into three categories according to their epithelial cell adhesion molecule status. These categories were highly correlated with the recently revised American Joint Committee on Cancer staging system for breast cancer, demonstrating the clinical relevance of this simple and reliable immunomagnetic technique. We also evaluated immunocytochemical detection of cytokeratin-positive cells and cytomorphological parameters. Immunocytochemistry-based methods for the detection of BM micrometastases did not provide any information about the clinical status of patients, but helped to refine the immunomagnetic data by confirming the presence of micrometastases in some cases. We also tested a new density gradient centrifugation system, able to enrich the tumor fraction of BM specimens by twofold to threefold as compared with standard Ficoll methods.

Conclusion These improved methods for the detection of micrometastatic cells in patient BM should help clinicians to predict the clinical status of breast cancer patients at the time of surgery or treatment.

Keywords: bone marrow, breast cancer, clinical staging, immunodetection, micrometastases

\section{Introduction}

The most recent estimate of the 10-year relative survival rate for breast cancer patients is 78\% [1]. At the time of surgery, the clinical prediction of relapse is still based on the determination of prognostic parameters in the primary tumor or locoregional lymph nodes. However, histopathological evaluation often fails to predict the risk of relapse.
Hematogeneous dissemination of occult isolated tumor cells, so-called 'micrometastases', appears to be the leading cause of overt metastasis development. The prognostic value of finding micrometastatic cells in bone marrow (BM) aspirates of carcinoma patients has been demonstrated $[2,3]$. The accurate detection of these cells may therefore provide additional information for early diagnosis, and may

$\overline{\mathrm{AJCC}}=$ American Joint Committee on Cancer; $\mathrm{BM}=$ bone marrow; $\mathrm{BSA}=$ bovine serum albumin; $\mathrm{CK}=$ cytokeratin; EpCAM $=$ epithelial cell adhesion molecule; HBSS = Hank's balanced salt solution; $I C=$ immunocytochemistry; $I M=$ immunomagnetic; $M N C=$ mononuclear cells; PBS = phosphatebuffered saline; $\mathrm{PCR}=$ polymerase chain reaction; $\mathrm{RT}=$ reverse transcription; $\mathrm{TBC}=$ Tris-buffered saline. 
help clinicians to select patients for adjuvant therapy and to monitor patients during follow-up. The purification of micrometastatic cells should improve the characterization of the metastatic process, and should facilitate the development of new tools and approaches to target the 'minimal residual disease'.

The methods currently used to evaluate the spreading of micrometastases are immunocytochemistry (IC) $[4,5]$, RTPCR $[6,7]$, flow cytometry $[8,9]$, fluorescence in situ hybridization [10,11], and immunomagnetic (IM) bead enrichment [12-15]. Most of these methods rely on the expression of epithelial markers on the membrane or the cytoskeleton of carcinoma cells collected from blood or BM after density gradient centrifugation (Ficoll) of the mononuclear cell (MNC) fraction. As disseminated tumor cells are rare in the BM of breast cancer patients (one to 10 per million MNCs), these techniques have to be particularly sensitive and specific to the large spectrum of genes expressed in BM cells. IM bead enrichment techniques are therefore considered an essential step in carcinoma cell detection and purification. We further assessed the power and limitations of this technique. We optimized the IM method for the detection and purification of tumor cells disseminated in the BM of breast cancer patients [16]. However, this method also purified a small but significant number of BM cells that contaminated the tumor fraction.

In the present study, we first evaluated the clinical relevance of the optimized IM technique, using control BM specimens and BM aspirates from breast cancer patients with 'localized disease' or 'advanced disease'. Analysis of patients' clinical records revealed a correlation between cancer stage and IM data. Second, we compared the IM method with the IC method for the detection of BM micrometastases, and introduced a more efficient Ficoll procedure into the standard IC protocol. For both techniques, we assessed the contamination of the final fraction with BM cells and the heterogeneity of the pattern of epithelial cell adhesion molecule (EpCAM) and cytokeratin (CK) marker expression.

\section{Materials and methods Patients}

After obtaining written informed consent, BM aspirates were collected from breast cancer patients at the Medical Division of the Institut Curie. Samples were collected before starting chemotherapy. Samples were collected under general anesthesia for 10 patients undergoing primary tumor surgery and were collected under local anesthesia for 22 patients with advanced stages of disease. The mean age of the patients was $50 \pm 8$ years. Data were collected blindly. Patient characteristics were prospectively recorded on the Institut Curie medical files. Medical records included the patient's hormonal (estrogen and progesterone) receptor and Her2 status, histology, grading and staging of tumors.

BM cells from 46 control patients undergoing hip surgery were sampled in the Orthopedic Department of Hôpital Cochin (Paris, France). The mean age of the patients was $62 \pm 14$ years, and the medical records for each patient were checked to ensure that they never had previous carcinoma.

\section{BM processing}

Needle aspirates from the upper iliac crest of breast cancer patients were collected in EDTA K3 Vacutainer tubes (Becton Dickinson, Franklin Lakes, NJ, USA). Sample volumes ranged from 2 to $15 \mathrm{ml}$ (mean, $5 \pm 4 \mathrm{ml}$ ), yielding $138 \pm 90$ million nucleated cells, which is a mean concentration of 28 million nucleated cells per milliliter. Control BM samples were collected in sodium citrate Vacutainer tubes. Sample volumes ranged from 4 to $22 \mathrm{ml}$ (mean, $14 \pm 4 \mathrm{ml}$ ), yielding $656 \pm 447$ million nucleated cells, which is a mean concentration of 47 million nucleated cells per milliliter.

BM aspirates were processed immediately or kept at $4^{\circ} \mathrm{C}$ for no longer than overnight. After washing in a 10 -fold volume of Hank's balanced salt solution (HBSS), BM samples were resuspended in HBSS and layered over a Ficoll solution (HistoPaque-1077; Sigma Diagnostic, St Louis, MO, USA) in $10 \mathrm{ml}$ LeucoSep tubes (VWR International, Darmstadt, Germany), before being centrifuged at $400 \times g$ for $20 \mathrm{~min}$. The resulting gradient density interface was collected and washed in $0.1 \%$ BSA in PBS. The OncoQuick (Greiner Bio-One, Frickenhausen, Germany) gradient density centrifugation system was tested on BM from several control patients and was compared with HistoPaque.

For IC experiments, Ficoll-purified cells were resuspended in $0.1 \% \mathrm{BSA}$ in PBS at $1 \times 10^{6} \mathrm{cells} / \mathrm{ml}$, and were cytospinned on polylysine-coated slides at $350 \times g$ for $2 \mathrm{~min}$ (Universal 16 Cytocentrifuge; Hettich, Kirchlengern, Germany). After overnight air drying, slides were either processed immediately for immunochemistry or fixed for $5 \mathrm{~min}$ in $4 \%$ formaldehyde and $0.2 \%$ sucrose in PBS, before being stored at $-20^{\circ} \mathrm{C}$ for up to 6 months.

For IM experiments that did not include a Ficoll step, clots and clumps were first removed by pipetting up and down. An aliquot containing 50 million nucleated cells was washed in a 10-fold volume of HBSS. After centrifugation at $570 \times g$ for $15 \mathrm{~min}$, the pellet was resuspended in $2 \mathrm{ml}$ of $1 \% \mathrm{BSA}$ in PBS at $4^{\circ} \mathrm{C}$, and was kept on ice until processing.

\section{Cell lines}

MCF7 and T47D cell lines originate from human breast carcinoma pleural effusions (ATCC, Manassas, VA, USA). 
Cells were cultured under appropriate conditions and were shown to be mycoplasma-free.

For spiking assays, cell lines were first labeled for $45 \mathrm{~min}$ at $37^{\circ} \mathrm{C}$ with a vital dye probe (5-chloromethylfluorescein diacetate; Molecular Probes, Eugene, OR, USA) before being added to BM samples. This bright-green, long-lasting, fluorescent dye can detect as few as 10 live cells among 50 million nucleated BM cells.

\section{Antibodies}

The MOC31 monoclonal antibody (kindly given by Prof. O. Fodstad, The Norwegian Radium Hospital, Oslo, Norway) is directed against an extracellular epitope of the EpCAM, and was used at a final concentration of $1 \mu \mathrm{g} / \mathrm{ml}$. A45-B/ B3 (Chromavision Medical Systems Inc., San Juan Capistrano, CA, USA) recognizes a common epitope of the epithelial CK8, CK18 and CK19. Immunolabeling with A45-B/ B3 $(1 \mu \mathrm{g} / \mathrm{ml}$ final concentration) is possible after fixing cells for $5 \mathrm{~min}$ in $4 \%$ formaldehyde and $0.2 \%$ sucrose in PBS. The anti-human leukocyte common antigen CD45 $(4 \mu \mathrm{g} / \mathrm{ml}$ final concentration), murine $\operatorname{lgG}_{1}(2 \mu \mathrm{g} / \mathrm{ml}$ final concentration), and rabbit anti-mouse ( $175 \mu \mathrm{g} / \mathrm{ml}$ final concentration) antibodies, as well as the alkaline phosphatase-anti-alkaline phosphatase ( $1 \mu \mathrm{g} / \mathrm{ml}$ final concentration), were purchased from Dako (Glostrup, Dennmark).

\section{Immunocytochemistry}

One million cells per cytospot were immunolabeled at room temperature with the A45-B/B3 pan-CK antibody, as previously described [17]. Briefly, cells were fixed for $5 \mathrm{~min}$ in $4 \%$ formaldehyde and $0.2 \%$ sucrose in PBS, were blocked for $20 \mathrm{~min}$ in 10\% human serum albumin in Tris-buffered saline (TBS), and were incubated for $45 \mathrm{~min}$ with $1 \mu \mathrm{g} / \mathrm{ml}$ A45-B/B3 or $2 \mu \mathrm{g} / \mathrm{ml}$ murine $\operatorname{lgG}_{1}$ antibodies in TBS, and for $15 \mathrm{~min}$ with $175 \mu \mathrm{g} / \mathrm{ml}$ rabbit anti-mouse antibody in TBS. The immune complex was revealed by the alkaline phosphatase-anti-alkaline phosphatase/Fuchsin procedure, as described previously [18]. The whole immunolabeling protocol was performed using a Cadenza automated apparatus (Shandon, San Marcos, CA, USA), and included 5 -min washing steps between each incubation. Cytospots were then counterstained for 2-3 $\mathrm{min}$ in a 1/3 dilution of Mayer's hematoxylin solution (Sigma, St Louis, MO, USA). After rinsing in tap water for $5 \mathrm{~min}$, slides were mounted with Faramount mounting medium (Dako) and were screened using an ACIS automated digital microscope (Chromavision).

For each patient, three cytospots (i.e. $3 \times 10^{6}$ cells) were labeled with $\mathrm{A} 45-\mathrm{B} / \mathrm{B} 3$, and three other cytospots were used as negative controls. A positive control slide bearing the MCF7 breast carcinoma cell line was included in each experiment. Images of immunoreactive cells were recorded with the ACIS software (Chromavision) and were reviewed by a pathologist. Slides were manually analyzed by an independent pathologist in a blind manner, in order to check the morphology of labeled cells.

\section{IM enrichment}

M450 magnetic beads (Dynal, Oslo, Norway) coated with sheep anti-mouse $\operatorname{lgG}$ were conjugated to the MOC31 (anti-EpCAM) monoclonal antibody. After washing in the presence of a magnet, beads were coated with $2 \mu \mathrm{g}$ antibody per milligram of beads, for at least 2 hours at $4^{\circ} \mathrm{C}$ in $500 \mu \mathrm{l}$ of $1 \%$ BSA in PBS (bead buffer). After washing to remove excess antibody, the bead suspension $\left(4 \times 10^{8}\right.$ beads $/ \mathrm{ml}$ ) was ready to use and was stored in bead buffer at $4^{\circ} \mathrm{C}$ for up to 3 months.

The standard IM protocol was modified as follows [16]. For each experiment, 50 million nucleated BM cells per tube were subjected to IM enrichment. The reaction was performed with $10 \mu \mathrm{l}$ bead suspension, in bead buffer at $4^{\circ} \mathrm{C}$ for $30 \mathrm{~min}$ under rotation in a $2 \mathrm{ml}$ total volume. After washing twice in $5 \mathrm{ml}$ ice-cold bead buffer, $50 \mu \mathrm{l}$ RosetteSep antibody cocktail (StemCell Technologies, Vancouver, Canada) was added and incubated for an additional $20 \mathrm{~min}$ at $4^{\circ} \mathrm{C}$. These bispecific antibody complexes recognize CD45-positive (lymphoid cells) and CD66b-positive (granulocytes) cells, and recognize glycophorin A on erythrocytes. These unwanted cells were thus cross-linked and eradicated during a third washing step. The resulting IM pellet was then collected in a $50 \mu \mathrm{l}$ total volume and the whole fraction was analyzed on glass slides under a light microscope. Cells with visible nuclei or membranes, measuring more than $12 \mu \mathrm{m}$, and rosetted with at least five beads, were considered positive.

\section{Immunofluorescence}

Immunopurified cells were left overnight on polylysinecoated slides. After fixing for 5 min in 4\% formaldehyde and $0.2 \%$ sucrose in PBS, and then washing in PBS, cells were incubated simultaneously with primary and secondary antibodies for 1 hour at room temperature. The Alexa-Fluor 488 goat anti-mouse lgG (Molecular Probes) was used as secondary antibody ( $2 \mu \mathrm{g} / \mathrm{ml}$ final concentration), and control experiments were performed in the absence of primary antibody. After mounting with Dako fluorescent mounting medium, slides were observed by fluorescence microscopy. Magnetic beads appeared fluorescent due to the reaction of their MOC31 monoclonal antibody coat with the secondary anti-mouse antibody.

\section{Statistics}

Differences between the numbers of EpCAM-positive cells in the different patient populations were analyzed using the Wilcoxon tests for quantitative and nonparametic variables. Correlations between the IM groups and stages of disease, or the IC groups, were analyzed by chi-square tests for cat- 
egorical variables and by the Mann-Whitney $U$ test for comparison of two unpaired groups. The Kruskal-Wallis one-way test was used for multiple comparisons. Statistical analyses were performed using StatView Software 5.0 (SAS Institute Inc., Cary, NC, USA). Differences were considered significant if $P<0.05$.

\section{Results \\ IM detection of BM micrometastases and clinical staging of breast cancer}

IM bead purification techniques have improved the detection of micrometastases. As micrometastatic cells are extremely rare, none can be lost during the detection process. We thus optimized the standard IM technique based on EpCAM antigen recognition. This optimized assay can process an entire crude BM specimen in less than 1 hour and results are analyzed on just one slide. This highly reproducible technique is able to recover as few as 10 tumor cells among 50 million nucleated BM cells, with a recovery yield of about $100 \%$ and only $0.01 \%$ nonspecific cell draining [16].

We used this technique to seek MOC31-positive cells in BM aspirates from 32 breast cancer patients in a blind manner (Table 1). Medical records showed that the patients analyzed were representative of the overall breast cancer population; $81 \%$ tested positive for estrogen receptors and/or progesterone receptors, $18 \%$ tested positive for Her2/neu, and 17\% exhibited lobular invasive carcinomas versus ductal invasive carcinomas. The tumor grade distribution was $19 \%, 36 \%$ and $45 \%$ for grade I, grade II and grade III, respectively.

The recently revised American Joint Committee on Cancer (AJCC) staging system for breast cancer [19] was used to divide patients into two groups. The 'localized disease' group $(n=10)$ included stage I and stage IIA patients, most of whom were recruited at the time of initial surgery. These patients have T1 and T2 tumor sizes, and less than four positive lymph nodes. The 'advanced disease' group ( $n=$ 22) included stage IIIA-C and stage IV patients. Most of these patients were recruited before starting initial chemotherapy. They exhibit inflammatory tumors or T2, T3 and T4 tumor sizes, and in most cases exhibit a number of positive lymph nodes.

\section{Prognostic significance of the IM detection of EpCAM- positive cells in BM of breast cancer patients}

We have previously reported the limitations of the EpCAMbased IM technique, due to the ability of some BM cells to express EpCAM antigens and to contaminate the immunopurified fraction [16]. We therefore used the IM method to seek EpCAM-positive cells in 46 control BM specimens, and in the 10 'localized disease' and the 22 'advanced disease' breast cancer BM aspirates (Fig. 1). A mean of $68 \pm$
51 MOC31-positive cells were detected in control samples (group 1), compared with $84 \pm 74$ in the 'localized disease' patients (group 2) and $192 \pm 100$ in the 'advanced disease' patients (group 3). The nonparametric Wilcoxon statistic test showed that the differences between group 1 and group 3 , and between group 1 and groups $2+3$ are significant $(P<0.0001)$. However, no significant difference was found between group 1 and group $2(P=0.6226)$ or between group 2 and group $3(P=0.0115)$.

Based on the median number of MOC31-positive cells (60 cells for group 1, 101 cells for group 2, and 176 cells for group 3), we divided the patients into three groups on the basis of a priori defined threshold values. Indeed, all 'advanced disease' patients had more than 50 MOC31positive cells per 50 million nucleated BM cells analyzed, whereas only five of the 56 control and 'localized disease' patients had more than 150 cells. Figure 2 shows the distribution of patients within these three groups: $64 \%$ of 'advanced disease' patients were in group $A$, whereas group $B$ contained patients of each category, and group C included only control and 'localized disease' patients. This classification system, based on the number of cells detected and the 'clinical category', is highly relevant as attested by the chi-square statistical test $(P<0.0001)$.

We subsequently divided the patients in these three IM groups into two categories based on the 2002 AJCC tumor staging system (Table 2). Only one patient out of 15 was misclassified in group $A$, which is equivalent to only $7 \%$ nonspecific prediction among stage IIIA-C and stage IV patients. All patients in group $\mathrm{C}$ were correctly predicted to be at stage I or stage IIA. Chi-square analysis revealed a strong correlation $(P=0.005)$ between the stage and the IM group, and the Kruskal-Wallis nonparametric test revealed a strong correlation between the stage and the mean cell number $(P=0.0049)$. These data demonstrate the clinical relevance of this optimized IM method, based on a quantification of EpCAM-positive cells trapped in patient BM.

\section{Improvement in the density gradient centrifugation system for tumor cell enrichment from BM aspirates}

We compared a new density gradient centrifugation protocol (OncoQuick) with the standard method usually referred to as Ficoll (HistoPaque). OncoQuick was developed for blood cell separation and presents the advantage of removing leukocytes from the collected MNC fraction. To assess the OncoQuick protocol for BM sample enrichment, we carried out a model experiment where breast cancer metastatic cell lines (MCF7, T47D, BC-H1) were labeled with the 5-chloromethylfluorescein diacetate vital fluorescent dye, and were mixed with control BM before density gradient centrifugation processing. 
Table 1

\begin{tabular}{|c|c|c|c|c|c|c|c|c|c|}
\hline $\begin{array}{l}\text { IM EpCAM- } \\
\text { positive cells }\end{array}$ & Patients & $\begin{array}{l}\text { Hormonal } \\
\text { receptor- } \\
\text { positive }^{\mathrm{a}}\end{array}$ & $\begin{array}{l}\text { Her2/neu } \\
\text { positive }\end{array}$ & Histology & $\begin{array}{l}\text { Tumor } \\
\text { grade }\end{array}$ & Tumor size & $\begin{array}{l}2002 \text { AJCC } \\
\text { nodes pN }\end{array}$ & $\begin{array}{l}2002 \text { AJCC } \\
\text { stage }\end{array}$ & $\begin{array}{l}\text { Patient 'disease' } \\
\text { group }\end{array}$ \\
\hline 103 & PM549 & 1 & 0 & $\mathrm{DI}$ & II & NA & 3 & IV & 'Advanced' \\
\hline 179 & PM551 & 1 & 0 & $\mathrm{DI}$ & III & T3 & 2 & IIIA & 'Advanced' \\
\hline 214 & PM552 & 0 & 0 & $\mathrm{DI}$ & III & $\mathrm{T} 4$ & 2 & IIIB & 'Advanced' \\
\hline 42 & PM557 & 1 & 0 & DI & II & $\mathrm{T} 1$ & 0 & I & 'Localized' \\
\hline 7 & PM566 & 1 & 0 & $\mathrm{DI}$ & I & $\mathrm{T} 1$ & 0 & I & 'Localized' \\
\hline 17 & PM567 & 1 & 0 & $\mathrm{DI}$ & II & $\mathrm{T} 1$ & 1 & $\| A$ & 'Localized' \\
\hline 7 & PM568 & 1 & 0 & DI & II & $\mathrm{T} 2$ & 1 & $\| A$ & 'Localized' \\
\hline 180 & PM572 & 1 & 0 & $\mathrm{DI}$ & III & $\mathrm{T} 2$ & 2 & IIIA & 'Advanced' \\
\hline 101 & PM596 & 1 & 0 & $\mathrm{DI}$ & I & $\mathrm{T} 1$ & 0 & I & 'Localized' \\
\hline 37 & PM597 & 1 & 1 & $\mathrm{LI}$ & II & $\mathrm{T} 1$ & 0 & I & 'Localized' \\
\hline 278 & PM598 & 1 & 1 & DI & II & $\mathrm{T} 4$ & 2 & IIIB & 'Advanced' \\
\hline 255 & PM601 & 0 & 0 & $\mathrm{DI}$ & III & NA & 0 & IV & 'Advanced' \\
\hline 358 & PM602 & 1 & 1 & $\mathrm{DI}$ & III & $\mathrm{T} 4$ & NA & IIIB & 'Advanced' \\
\hline 142 & PM603 & 1 & 1 & $\mathrm{DI}$ & III & $\mathrm{T} 4$ & 2 & IIIB & 'Advanced' \\
\hline 146 & PM608 & 1 & 0 & $\mathrm{DI}$ & I & $\mathrm{T} 1$ & 0 & 1 & 'Localized' \\
\hline 229 & PM609 & 0 & 0 & $\mathrm{DI}$ & III & T2 & 0 & $\| A$ & 'Localized' \\
\hline 162 & PM612 & 1 & 0 & DI & II & T3 & 2 & IIIA & 'Advanced' \\
\hline 143 & PM613 & 1 & 0 & $\mathrm{DI}$ & I & $\mathrm{T} 1$ & 0 & I & 'Localized' \\
\hline 115 & PM615 & 1 & 0 & $\mathrm{DI}$ & II & $\mathrm{T} 2$ & 0 & $\| A$ & 'Localized' \\
\hline 215 & PM618 & 1 & 0 & $\mathrm{LI}$ & III & NA & 3 & IV & 'Advanced' \\
\hline 140 & PM620 & 1 & 0 & $\mathrm{DI}$ & III & T3 & 3 & IIIC & 'Advanced' \\
\hline 67 & PM631 & 1 & 0 & $\mathrm{LI}$ & II & Т3 & 3 & IIIC & 'Advanced' \\
\hline 172 & PM632 & 0 & 0 & $\mathrm{DI}$ & III & NA & 3 & IV & 'Advanced' \\
\hline 345 & PM634 & 1 & 1 & $\mathrm{DI}$ & II & T3 & 2 & IIIA & 'Advanced' \\
\hline 87 & PM635 & 1 & 0 & $\mathrm{LI}$ & NA & $\mathrm{T} 4$ & 2 & IIIB & 'Advanced' \\
\hline 79 & PM642 & 1 & 0 & DI & I & $\mathrm{T} 4$ & 2 & IIIB & 'Advanced' \\
\hline 162 & PM643 & 0 & 0 & $\mathrm{DI}$ & III & $\mathrm{T} 4$ & 0 & IIIB & 'Advanced' \\
\hline 105 & PM644 & 0 & 1 & $\mathrm{DI}$ & III & T3 & 3 & IIIC & 'Advanced' \\
\hline 223 & PM649 & 1 & 0 & $\mathrm{DI}$ & III & $\mathrm{T} 2$ & 2 & IIIA & 'Advanced' \\
\hline 88 & PM655 & 1 & 0 & $\mathrm{DI}$ & III & T2 & 2 & IIIA & 'Advanced' \\
\hline 216 & PM656 & 1 & 0 & $\mathrm{LI}$ & II & $\mathrm{T} 4$ & 1 & IIIB & 'Advanced' \\
\hline 458 & PM658 & 1 & 0 & $\mathrm{LI}$ & I & $\mathrm{T} 2$ & 3 & IIIC & 'Advanced' \\
\hline
\end{tabular}

AJCC, American Joint Committee on Cancer; DI, ductal invasive; EpCAM, Epithelial Cell Adhesion Molecular; IM, immunomagnetic; LI, lobular invasive; NA, not available; pN, pathologic lymph node status ${ }^{2} 1$, positive; 0 , negative.

The amounts of BM and tumor cells recovered were then determined (Table 3). The OncoQuick and HistoPaque techniques decreased the number of nucleated BM cells in the enriched cell fraction by between 9 -fold and 14.5 -fold and by between 1.5 -fold and 2.5 -fold, respectively. Indeed, $10 \%$ and $51 \%$ of BM cells remained in the purified fraction using the two techniques, respectively, when 100 million 


\section{IM MOC31-positive cell numbers}

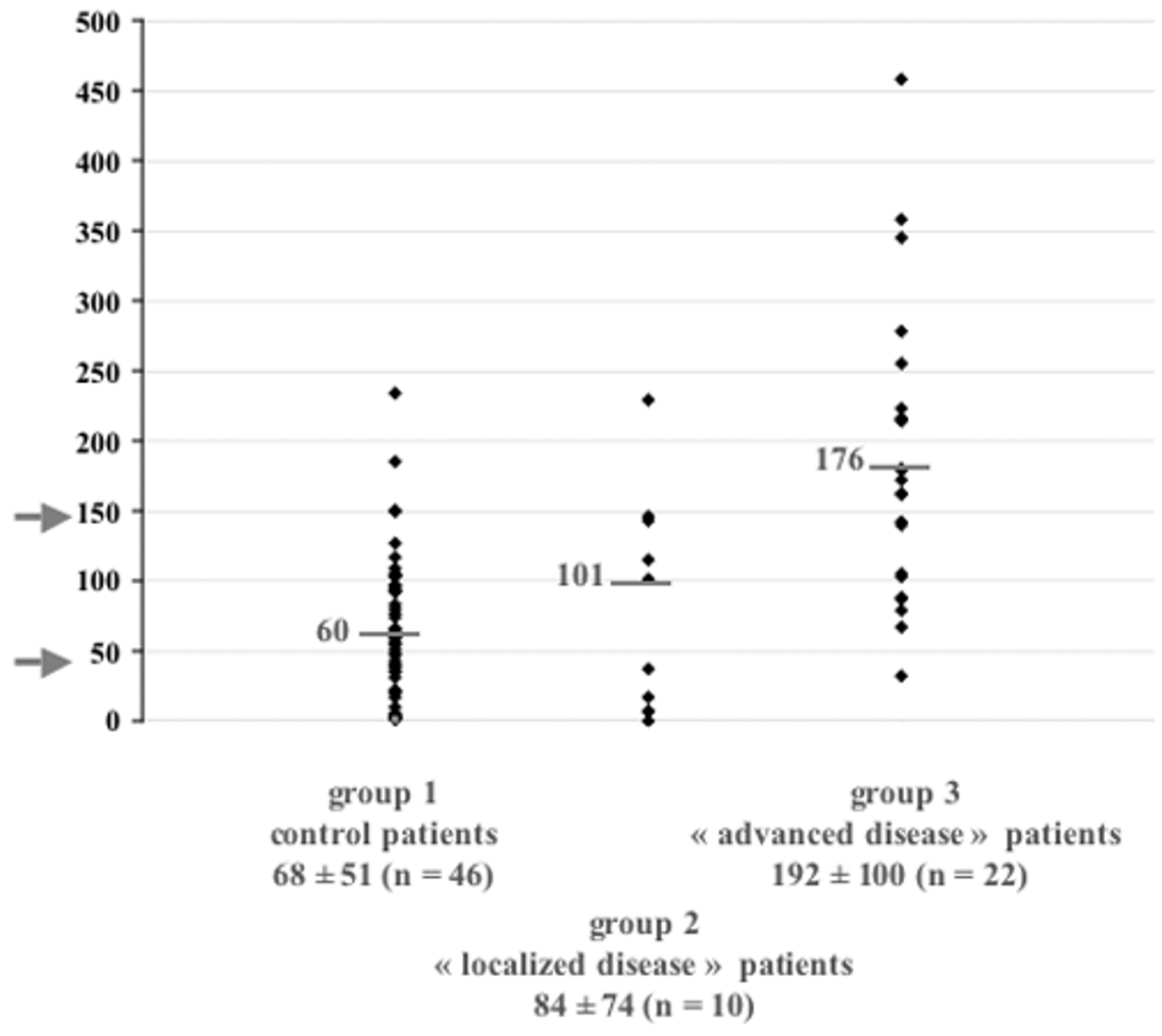

Prognostic significance of the immunomagnetic (IM) detection of bone marrow (BM) micrometastases in patients. The number of MOC31-positive cells detected was compared in 46 control patients (group1), and in 10 patients with 'localized' breast cancer (group 2) and 22 patients with 'advanced' breast cancer (group 3). Data are expressed as the number of MOC31-positive cells found in 50 million crude nucleated BM cells for each patient. The median and mean number of cells \pm standard deviation of the mean are presented for each patient group.

cells were added. As a result, fivefold fewer cytospots have to be screened with the standard IC procedure to detect micrometastases in BM processed with the OncoQuick protocol.

When 200 T47D cells were mixed with 100 million nucleated $\mathrm{BM}$ cells, the mean recovery rates were $41 \%$ for
OncoQuick and $34 \%$ for HistoPaque. These data are in agreement with a mean recovery rate of $42 \%$ obtained with both methods for tumor cell enrichment from blood [20]. Although enrichment factors are 10-fold lower in BM than in blood, the OncoQuick density gradient centrifugation protocol provides real improvements compared with stand- 


\section{Patient distribution}

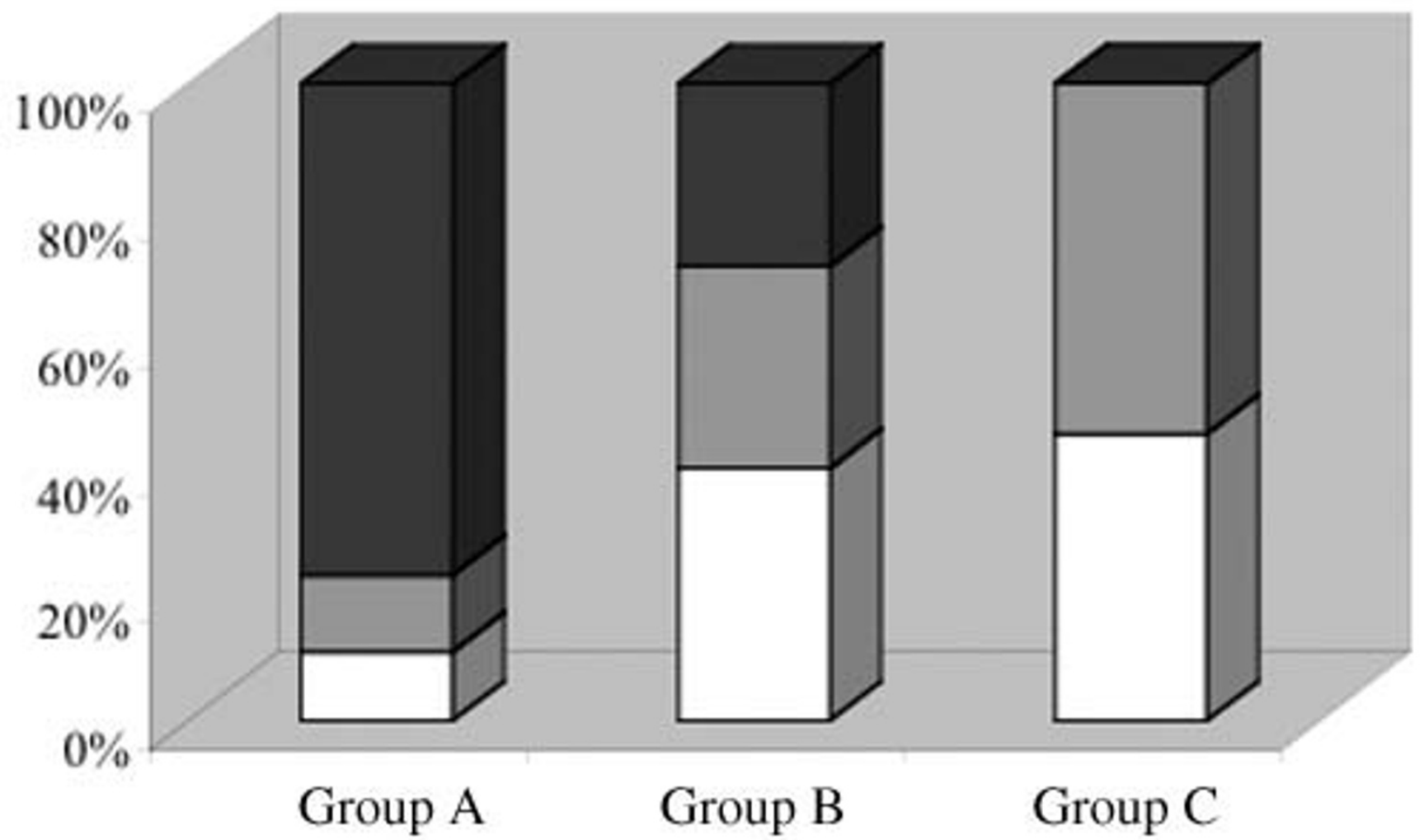

Classification of patients according to immunomagnetic detection of MOC31-positive cells in bone marrow (BM) specimens. BM samples from control patients (white), and from patients with 'localized' breast cancer (gray) and patients with 'advanced' breast cancer (black) were subjected to the immunomagnetic technique for the detection of MOC31-positive cells. These patients were then divided into three groups on the basis of the number of cells trapped: group A includes patients with more than 150 cells, group B includes those with 50-150 trapped cells, and group C includes those with less than 50 cells trapped among 50 million nucleated BM cells.

Table 2

Correlation between breast cancer patient staging and number of EpCAM-positive cells trapped in bone marrow aspirates

\begin{tabular}{|c|c|c|c|c|c|c|}
\hline \multirow{2}{*}{$\begin{array}{l}2002 \text { AJCC } \\
\text { stages }\end{array}$} & \multicolumn{6}{|c|}{ Patient classification based on IM EpCAM-positive cell numbers } \\
\hline & Group A (cells $\geq 150$ ) & $\underset{<150)}{\text { Group B }}(50<$ cells & Group C (cells $<50)$ & Total patients & $\begin{array}{l}\text { IM-positive cells } \\
\text { (mean } \pm \text { SD) }\end{array}$ & $\begin{array}{l}\text { IM-positive cells } \\
\text { (median) }\end{array}$ \\
\hline Stages I and IIA & 1 & 4 & 5 & 10 & $84 \pm 74$ & 72 \\
\hline $\begin{array}{l}\text { Stages IIIA-C } \\
\text { and IV }\end{array}$ & 14 & 8 & 0 & 22 & $192 \pm 100$ & 176 \\
\hline Total patients & 15 & 12 & 5 & 32 & & \\
\hline $\begin{array}{l}\text { IM-positive cells } \\
\text { (mean } \pm \text { SD) }\end{array}$ & $243 \pm 85$ & $110 \pm 27$ & $22 \pm 17$ & & & \\
\hline $\begin{array}{l}\text { IM-positive cells } \\
\text { (median) }\end{array}$ & 216 & 104 & 17 & & & \\
\hline
\end{tabular}

AJCC, American Joint Committee on Cancer; EpCAM, Epithelial Cell Adhesion Molecule; IM, immunomagnetic; SD, standard deviation of the mean. 
Table 3

Comparison of density gradient centrifugation systems for the enrichment of disseminated tumor cells in bone marrow (BM)

\begin{tabular}{lll}
\hline After Ficoll & Gradient System & \\
\cline { 2 - 3 } & HistoPaque & OncoQuick \\
\hline Tumor cells recovered (\%) & $34 \pm 2$ & $41 \pm 8$ \\
BM cells remaining (\%) & $51 \pm 5$ & $10 \pm 1$ \\
BM mononuclear cell enrichment factor & $1.5-2.5$ & $9-14.5$ \\
Number of slides & 51 & 10 \\
\hline
\end{tabular}

ard Ficoll; first, by increasing the tumor cell density in BM samples and, second, by reducing the number of slides that need to be analyzed to achieve a more representative result.

\section{Relevance of IC detection of CK-positive cells in BM of breast cancer patients}

Micrometastases were detected by IC and by IM in parallel using BM aspirates from breast cancer patients. Ten out of the 32 (31\%) BM samples examined were positive for CKexpressing cells, in agreement with previous studies [2,3]. The frequency of CK-positive cells was between 1 and 11 cells per 3 million BM MNC screened (Fig. 3a). One patient (PM634), who was stage IIIA at the time of diagnosis, exhibited a tremendous amount of CK-positive cells (Fig. 3b). This situation was predictive of short-term bone metastasis development followed by death. The median number of CK-positive cells was 3.5, which is about one cell per million BM MNC screened.

Besides the difficulty in quantifying micrometastases with this technique, pathologists reported some nonspecific labeling of plasmocytes, megakaryocytes, and osteoclasts present in BM. We therefore used criteria adapted from Borgen and colleagues [21] and based on the European ISHAGE (International Society of Hematotherapy and Graft Engineering) Working Group standardization of tumor cell detection to classify patients: $12 \%$ of patients harbored CK-positive cells with typical tumor cell morphologies (class A), 19\% of patients harbored CK-positive cells with no convincing tumor or hematopoietic cell characteristics (class B), $22 \%$ of patients have hematopoietic or squamous skin epithelial CK-reactive (i.e. false-positive) cells (class C), and $47 \%$ of patients had purely CK-negative cells (class D). This distribution is in agreement with those reported in larger population trials $[17,21]$.

No correlation was found between the disease progression according to the 2002 AJCC tumor staging system with either CK-positive patients (chi-square test, $P=0.0804$ ) or the mean number of CK-positive cells (Kruskal-Wallis nonparametric test, $P=0.3238$ ).

\section{Correlation between the IC and IM methods for the detection of micrometastases in BM of breast cancer patients}

To compare these two immunodetection techniques further, we divided the 32 breast cancer patients into three IM groups and four IC classes, as defined earlier (Table 4). Importantly, none of the IM-negative patients (group C) were IC-positive (classes $A$ and $B$ ), meaning that our quantitative IM enrichment method detects every IC-positive patient. However, only $40 \%(6 / 15)$ of the IM-positive patients (group A) were IC-positive. Four of the 12 (33\%) patients in the IM group B were IC-positive, providing additional proof that they were micrometastases-positive. A combination of the IC technique and the IM enrichment method may thus increase the number of patients diagnosed as micrometastases-positive. However, no direct correlation could be established between the two techniques regarding the patients or the mean cell numbers, as assessed with the chi-square test $(P=0.2427)$ and the Kruskal-Wallis test $(P=0.5274)$, respectively.

This led us to address the significance of detecting EpCAM-positive versus CK-positive carcinoma cells in BM samples. A thorough analysis of the IC and the IM data demonstrated that the mean numbers of CK-positive and EpCAM-positive cells were 1.1 and 3.2 cells per million BM cells, respectively. This threefold difference may be explained by the fact that the IC technique screens only $6 \%$ of the BM aspirate and typically detects 0-3 cells/slide. Tumor cell losses during the indispensable Ficoll step performed before IC may also account for this discrepancy (32\% of cells remaining).

Another explanation could be the heterogeneity of expression of markers such as CK and EpCAM in carcinoma cells. As exemplified by immunofluorescence experiments (Fig. 4a), EpCAM-positive BM carcinoma cells may or may not 
(a)

\section{CK-positive patient distribution}

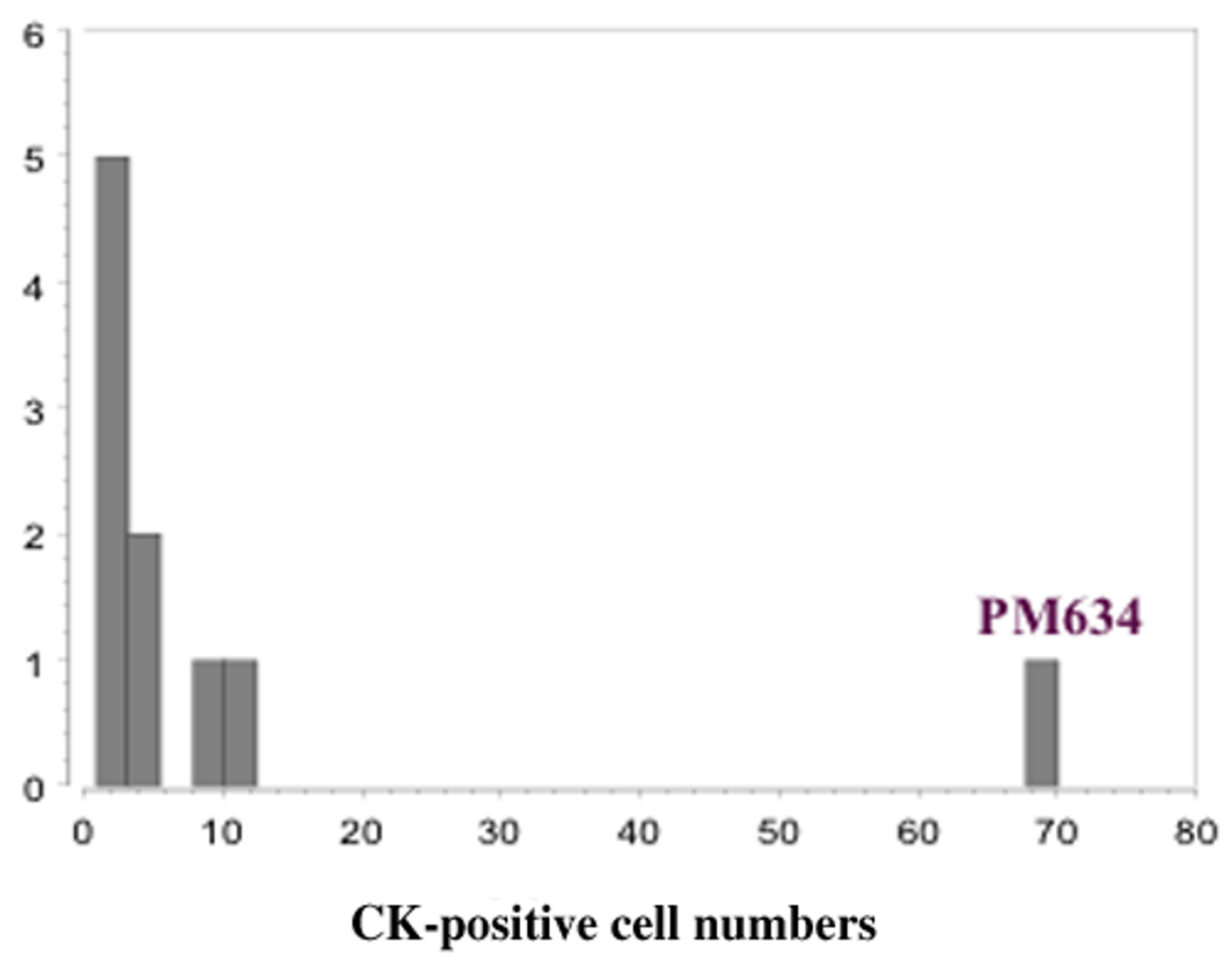

(b)

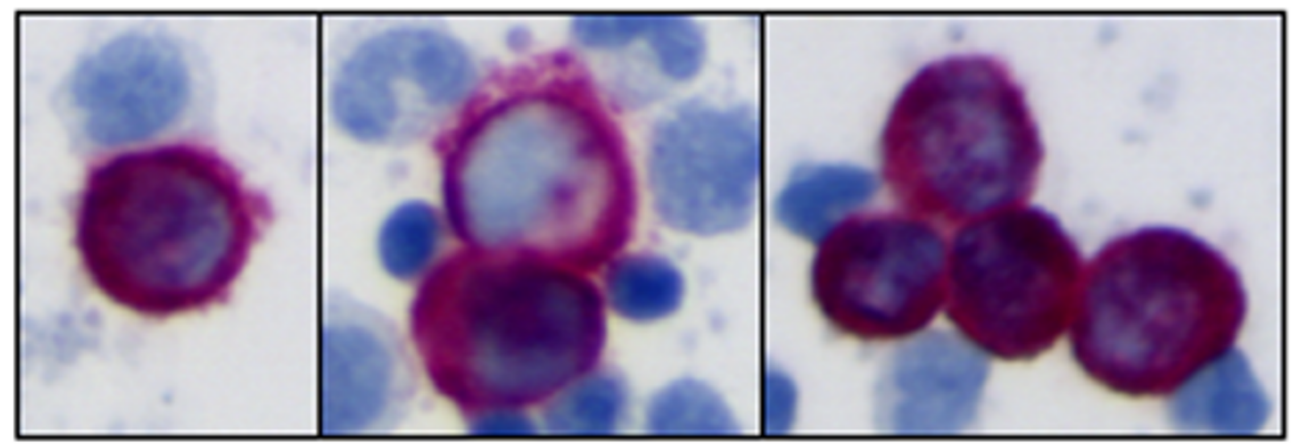

Immunocytochemistry targeting cytokeratins (CKs) in bone marrow (BM) aspirates from breast cancer patients. (a) Distribution of CK-positive cells for 32 patients. (b) CK-positive cells labeled (purple) by immunocytochemistry performed on BM mononuclear cell cytospots of one breast cancer patient with 'advanced disease' (PM634). 
Table 4

Correlation between immunocytochemistry (IC) cytokeratin (CK) -positive and immunomagnetic (IM) EpCAM-positive breast cancer patients

\begin{tabular}{|c|c|c|c|c|}
\hline \multirow[t]{2}{*}{ IC morphology } & \multicolumn{4}{|l|}{ IM patient classification } \\
\hline & Group A (cells $\geq 150$ ) & Group B $(50<$ cells $<150)$ & Group C (cells < 50) & Total patients \\
\hline Class A (CK-positive, morpho-positive) & 3 & 1 & 0 & 10 \\
\hline Class B (CK-positive, morpho-undefined) & 3 & 3 & 0 & \\
\hline Class C (CK-positive, morpho-negative) & 4 & 2 & 1 & 22 \\
\hline Class D (CK-negative, morpho-negative) & 5 & 6 & 4 & \\
\hline Total patients & 15 & 12 & 5 & 32 \\
\hline
\end{tabular}

CK, cytokeratin; EpCAM, Epithelial Cell Adhesion Molecule; morpho, tumor cell morphology.

express CK, reinforcing the idea that two different pools of carcinoma cells may be detected by the IM and the IC techniques. Moreover, anti-CK immunohistochemistry performed on primary tumor specimens from patients demonstrated the large heterogeneity in CK expression on carcinoma cells (data not shown). Finally, differences in nonspecific BM cell types and numbers, labeled with antiEpCAM and anti-CK antibodies, may introduce such a discrepancy. Indeed, some hematopoietic cells may express EpCAM molecules and thus be copurified with tumor cells in BM specimens, as documented both here (Fig. 4b) and elsewhere [16].

\section{Discussion}

We are still unable to predict accurately which patient will experience breast cancer progression after primary therapy. Improved methods for detecting and characterizing tumor cells deposited in various compartments of the body - primarily the lymph nodes, blood and BM - may provide a better estimate of the individual risk of relapse and may make it possible to design more effective therapies. There is growing evidence that there is no correlation between the presence of micrometastases in the lymph nodes, BM and blood, and that these three tissues may have distinct biological and clinical implications [22]. Peripheral blood should be an ideal source for micrometastatic cell detection. However, several studies failed to find any clinical relevance of the detection of these cells in blood or sentinel lymph nodes $[17,23,24]$. Over the past 5 years, large prospective studies have been conducted on primary breast carcinoma patients. All of them describe a significant correlation between the presence of immunostained tumor cells in BM and an unfavorable clinical outcome [3,22,2529]. Nevertheless, the reported incidence of BM micrometastatic cell detection fluctuates considerably due to variations in patient series, stage distribution, treatment, expression of the target antigen, sensitivity and specificity of the antibody used, and the procedures. Consensus guidelines have therefore been established by the ISHAGE European study group to standardize analyses.
With a standardized IC protocol, we detected CK-positive cells in the BM of 10/32 (31\%) breast cancer patients; seven of these patients $(70 \%)$ had less than four positive cells and two patients (20\%) had 10 or 11 positive cells per $3 \times 10^{6} \mathrm{BM}$ MNC analyzed. These data are in agreement with the 29\% ( $n=62$ ) of CK-positive patients described in a recent report, with $80 \%$ and $20 \%$ of patients having, respectively, 1-3 CK-positive cells and 6-10 CKpositive cells per $2 \times 10^{6} \mathrm{BM} \mathrm{MNC}$ analyzed [30]. Among the breast carcinoma patients positive for epithelial cells in $\mathrm{BM}$, the average number of tumor cells retrieved after IC was approximately $1-3$ cells per $1 \times 10^{6} \mathrm{BM} \mathrm{MNC}$. Usually, $3 \times 10^{6} \mathrm{MNC}$ are screened out of the $5-20 \times 10^{7}$ nucleated BM cells in the whole BM aspirate (i.e. only 1/20-1/ 70 of the biological sample). In such conditions, a very reproducible and calibrated technique is required.

Although the method has been standardized to some extent, we and other workers have observed considerable variations [21]. We think that it would be best to screen larger amounts of slides per patient, or to improve the enrichment procedure when using this assay. We have previously demonstrated that the tumor cell recovery rate after density gradient centrifugation (Ficoll) is only 34\% [16]. Heterogeneity in tumor cell buoyancy and the formation of cell clusters may account for this phenomenon. To circumvent this problem, we have tested a novel density centrifugation system (OncoQuick) that was initially developed to enrich carcinoma cells from peripheral blood [20]. A slight increase in the mean tumor cell recovery rate was observed (41\% compared with 39\% for blood [31]). A 3.6-fold to 9.3-fold increase in enrichment factor was obtained with OncoQuick as compared with standard Ficoll. The OncoQuick procedure thus considerably reduces the number of slides that need to be screened to achieve more quantitative results with IC. However, if the decision is still to rely on very few positive events, it emphasizes the importance of carefully characterizing the antibodies applied and the need to be aware of potential false-positive results. 
(a)
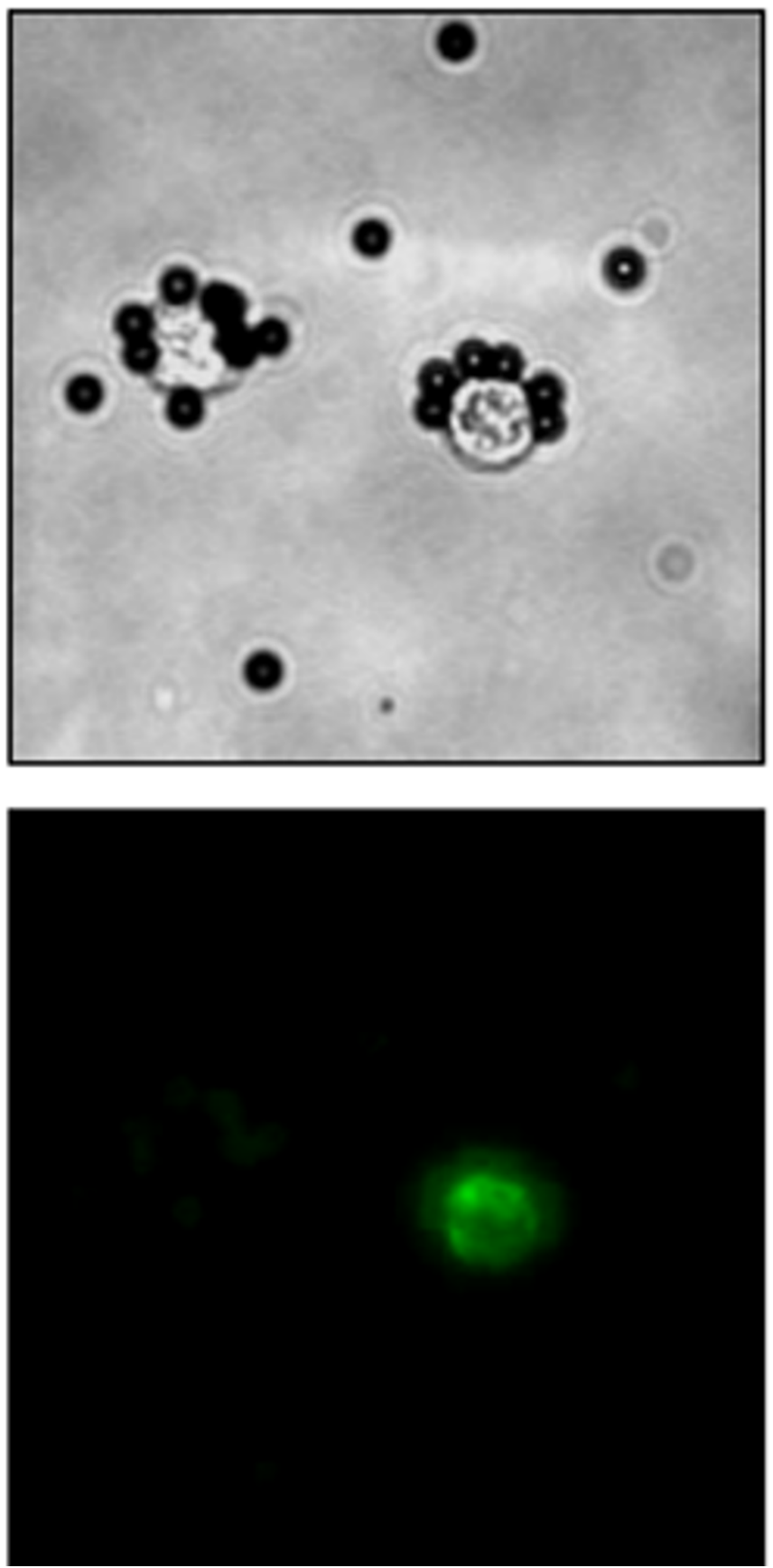

(b)
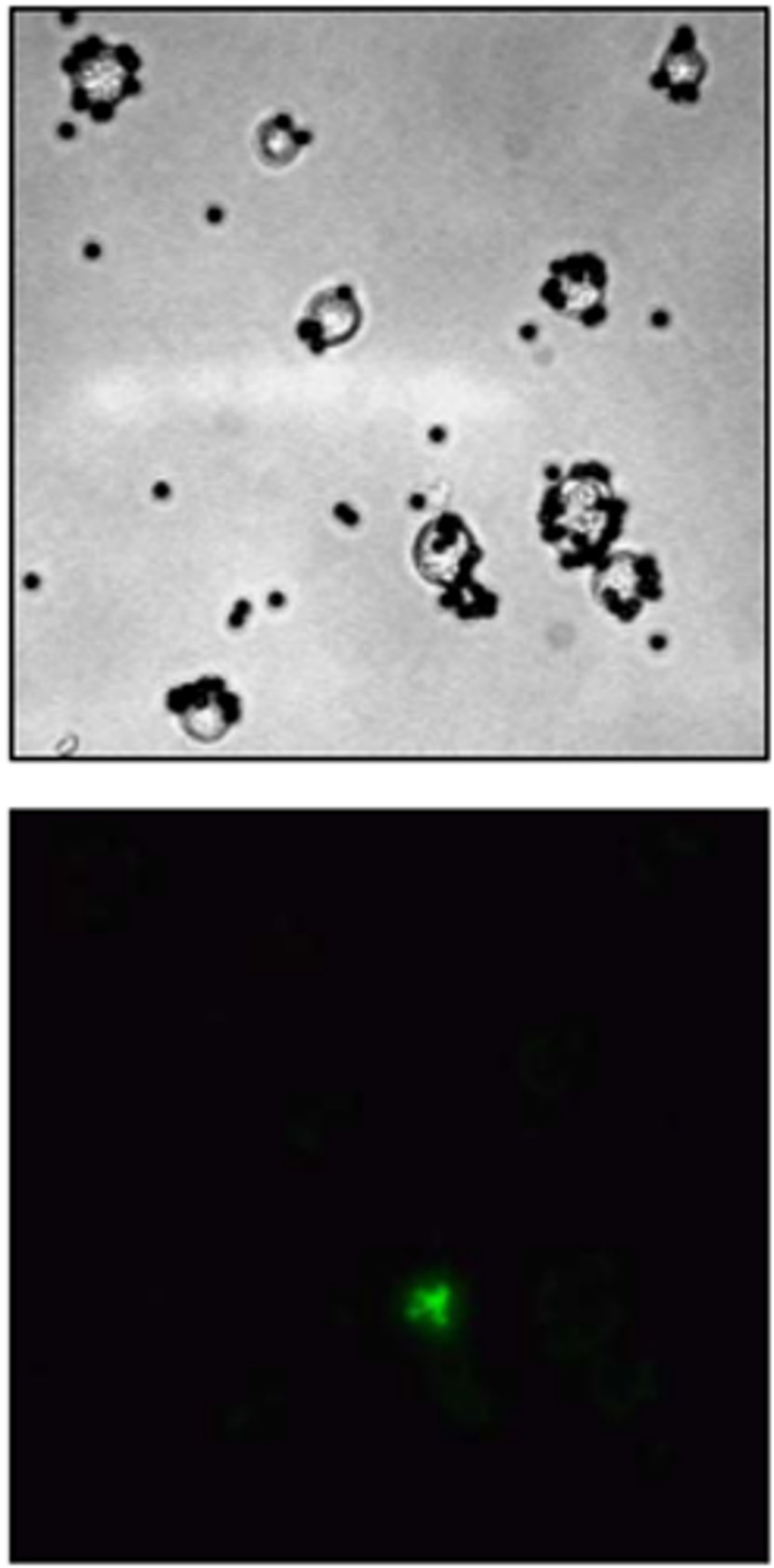

Immunomagnetic (IM) sorting and immunofluorescence characterization of bone marrow (BM) micrometastatic cells in 'advanced disease' breast cancer patients. BM aspirates were immunopurified using MOC31-conjugated Dynabeads. Following IM sorting, immunofluorescence experiments were performed using anti-cytokeratin (a) and anti-CD45 (b) antibodies (green labeling), and were analyzed by light/fluorescence microscopy. Magnification, $\times 400$ (a) and $\times 200$ (b). These data are representative of experiments performed with BM aspirates from several patients.

Immunostaining of several breast cancer metastatic cell lines (MCF7, T47D, BC-H1) and control BM MNC with different antibodies (A45-B/B3, AE1/AE3, KL1) targeting
CKs led us to choose the commonly used A45-B/B3 panCK antibody as a reference. We assume that some variability may occur due to slight differences in technical proce- 
dures (e.g. fixation protocols, antibody concentrations, and counterstaining solutions). The specificity of A45-B/B3 immunostaining needs to be carefully reappraised according to standardized criteria [21]. In our series, we found 6/ 32 (19\%) patients with A45-B/B3-positive cells, with unlikely tumor features and showing positive for control $\lg G_{1}$. This kind of false-positive staining may be the result of immunoglobulin kappa and lambda subunits reacting with the alkaline phosphatase-anti-alkaline phosphatase/ fuchsin substrate, as described on mature plasma cells [32]. In addition, BM cells identified by pathologists as plasmocytes, megakaryocytes, and osteoclastic cells may express CKs. IC detected such cells in 7/32 (22\%) patients. These observations are in agreement with the finding of rare A45-B/B3-positive cells in the BM of 7/20 $(35 \%)$ control patients [32]. False-positive immunostaining of hematopoietic cells and CK-expressing BM cells may thus interfere with the $\mathrm{IC}$ detection of micrometastatic cells in patient $\mathrm{BM}$.

Methods that can detect and further analyze more micrometastatic cells than the current IC technique are required. IM enrichment strategies confer an added advantage over IC because they can analyze the whole BM sample at once, thus increasing the sensitivity of tumor cell detection. We have developed a simple and highly reproducible IM protocol based on EpCAM antigen recognition [16]. This method can recover as few as 10 tumor cells among $5 \times 10^{7}$ nucleated BM cells, with a recovery yield of about $100 \%$ and only $0.01 \%$ nonspecific cell draining. However, the specificity of the method is hampered by the fact that subpopulations of hematopoietic cells and erythroid progenitors also express EpCAM and copurify with tumor cells in the sample.

In our series of 32 breast cancer patients with 'localized disease' and 'advanced disease', we assessed the clinical value of this IM assay by classifying patients on the basis of the recently revised AJCC staging system for breast cancer [19]. This emphasizes that a combination of high sensitivity and quantitative results is the most important advantage of IM enrichment, as the number of EpCAM-positive cells detected provides clinical significance. Previous studies using IM to detect BM micrometastatic cells in colorectal cancer patients failed to detect any correlation between the number of EpCAM-positive cells and the stage of disease [13].

We also show that IC detection of CK-positive cells for the same patient population is not correlated to the stage of disease. IC detection is of better prognostic value when clinical trials include a large number of patients (at least 100 ), but it cannot provide individual predictions. However, we demonstrate here that patient classification according to IM results may benefit from IC data.
Difficulties in finding correlations between the IM and IC methods for the detection of micrometastatic cells have been reported in the literature. Besides the difference in sensitivity due to different enrichment protocols, we suggest that both methods may detect different tumor cell subpopulations that differentially express the CK and EpCAM antigens. Indeed, we showed here and elsewhere [16] that EpCAM-positive BM cells may or may not express CK. Previous studies on breast cancer patients have reported that 68\% (range, 48-100\%) of CK-positive cells are EpCAMpositive in BM [33], and that only $28 \%$ of EpCAM-positive cells are CK-positive in blood [24]. A recent study performed on breast cancer patients treated with adjuvant chemotherapy reported that none of the CK-positive cells detected in BM using IC were EpCAM-positive, and that only $7.4 \%$ of BM specimens harbored CK-positive cells after EpCAM IM selection [30]. We agree that Ficoll processing might eliminate cell clusters or aggregates, leading to the preferential loss of EpCAM-expressing cells.

However, we believe that intrinsic tumor heterogeneity is the main explanation for the observed variations. Our assumption is based on the evaluation of A45-B/B3 immunostaining in primary tumor tissues for a set of ductal or lobular invasive carcinoma patients, which demonstrated large variations in CK expression (data not shown). In accordance, a comparison of breast cancer patient specimens using immunostaining and quantitative RT-PCR showed that EpCAM and CK19 mRNA levels vary considerably (> $10^{4}$-fold and $>10^{3}$-fold, respectively) in primary tumors, and that certain tumors cannot contain high or low levels of both markers simultaneously [34]. The expression level for EpCAM may vary between colorectal and breast cancer [35], or within breast cancer primary tumors in a bimodal (low or high) manner [36].

Additional heterogeneity may be generated by disseminated cells, which have to acquire invasive properties, escape immune mechanisms, adaptative and dormancy capacities before they can reach secondary sites such as BM. Previous studies have revealed the variable expression pattern of antigens in micrometastases [37]. The expression of the EpCAM antigen might be modulated during the proliferation and dedifferentiation steps that occur during the progression of cancer. EpCAM may be downregulated on metastatic tumor cells because loss of cell-cell adhesion is a prerequisite for tumor cell dissemination $[38,39]$. The epithelial-mesenchymal transition occurring in metastatic processes leads to a transient loss of EpCAM expression during the migratory and early postmigratory period [40]. The sole in vitro mechanism described that can account for EpCAM downregulation is a transcriptional effect induced by tumor necrosis factor alpha and mediated by nuclear factor kappaB [41]. 
Modulation of CK expression along with tumor progression has also been reported [42-44]. Major CK alterations observed in breast cancer could be reflected by the reduced or increased expression of individual CK, and by partial loss of the normal regulation of CK expression [45]. The fact that subsets of disseminated cells can express EpCAM and CK markers independently, and that carcinoma cells with low antigen expression may be missed by both methods, may account for the difficulty in reconciling IC and IM data.

\section{Conclusion}

The present study demonstrates that it is of uppermost importance to test rigorously the performance of techniques for detecting rare cells such as micrometastases, before carrying out large-scale clinical studies. Until a 'universal' and 'fully specific' surface antigen is discovered, a combination of markers, techniques, and approaches might help to overcome the limitations of detection procedures. Therefore, after evaluating the potential and the failure of the IM and IC methods, we have introduced substantial optimizations and demonstrated the clinical relevance of the quantitative IM technique in association with IC. This more accurate detection of BM micrometastatic cells may help to classify breast cancer patients and may constitute key information for the clinician in the administration of adjuvant therapy.

\section{Competing interests}

None declared.

\section{Acknowledgments}

The authors thank Dr Philippe Anract (Orthopedic Surgery Department, Hôpital Cochin) for providing the control BM specimens, Marianne Tuefferd for assistance with the statistical analyses, Martial Caly (Tumor Biology Department, Medical Division, Institut Curie) for technical assistance with immunocytochemistry, and Dr Jacqueline Jouanneau for constructive comments when writing the manuscript. Special thanks to patients for giving their consent to participate to this study.

This work was sponsored by the 'Programme Incitatif et Coopératif' on micrometastases at the Institut Curie.

The members of the Institut Curie Breast Cancer Group are: Bernard Asselain, Alain Aurias, Emmanuel Barillot, Francois Campana, Krishna Clough, Patricia De Cremoux, Olivier Delattre, Veronique Dieras, JeanMarc Extra, Alain Fourquet, Henri Magdelenat, Martine Meunier, Claude Nos, Thao Palangie, Pierre Pouillart, Marie-France Poupon, Francois Radvanyi, Xavier Sastre-Garau, Brigitte Sigal-Zafrani, Dominique Stoppa-Lyonnet, Anne Tardivon, Fabienne Thibault, Jean Paul Thiery, and Anne Vincent-Salomon.

\section{References}

1. Brenner $\mathrm{H}$ : Long-term survival rates of cancer patients achieved by the end of the 20th century: a period analysis. Lancet 2002, 360:1131-1135.

2. Pantel K, Cote RJ, Fodstad O: Detection and clinical importance of micrometastatic disease. J Natl Cancer Inst 1999, 91:1113-1124.
3. Braun S, Pantel K, Muller P, Janni W, Hepp F, Kentenich CR, Gastroph S, Wischnik A, Dimpfl T, Kindermann G, Riethmuller G, Schlimok G: Cytokeratin-positive cells in the bone marrow and survival of patients with stage I, II, or III breast cancer. N Engl J Med 2000, 342:525-533.

4. Janni W, Gastroph S, Hepp F, Kentenich C, Rjosk D, Schindlbeck C, Dimpfl T, Sommer H, Braun S: Prognostic significance of an increased number of micrometastatic tumor cells in the bone marrow of patients with first recurrence of breast carcinoma. Cancer 2000, 88:2252-2259.

5. Braun S, Cevatli BS, Assemi C, Janni W, Kentenich CRM, Schindlbeck C, Rjosk D, Hepp F: Comparative analysis of micrometastasis to the bone marrow and lymph nodes of node-negative breast cancer patients receiving no adjuvant therapy. J Clin Oncol 2001, 19:1468-1475.

6. Ikeda N, Miyoshi Y, Motomura K, Inaji H, Koyama H, Noguchi S: Prognostic significance of occult bone marrow micrometastases of breast cancer detected by quantitative polymerase chain reaction for cytokeratin 19 mRNA. Jpn J Cancer Res 2000, 91:918-924.

7. Aerts J, Wynendaele W, Paridaens R, Christiaens MR, vandenBogaert W, vanOosterom AT, Vandekerckhove F: A real-time quantitative reverse transcriptase polymerase chain reaction (RT-PCR) to detect breast carcinoma cells in peripheral blood. Ann Oncol 2001, 12:39-46.

8. Leers MPG, Schoffelen R, Hoop JGM, Theunissen P, Oosterhuis JWA, Bijl HV, Rahmy A, Tan W, Nap M: Multiparameter flow cytometry as a tool for the detection of micrometastatic tumour cells in the sentinel lymph node procedure of patients with breast cancer. J Clin Pathol 2002, 55:359-366.

9. Zoli W, Barzanti F, Dal Susino M, De Paola F, Tesei A, Ricotti L, Padovani F, Reno F, Amadori D: Flow-cytometric determination of tumor cells in lymph nodes. Oncology 2002, 62:128-135.

10. Forus A, Hoifodt HK, Overli GE, Myklebost O, Fodstad O: Sensitive fluorescent in situ hybridisation method for the characterisation of breast cancer cells in bone marrow aspirates. Mol Pathol 1999, 52:68-74.

11. Hosch S, Kraus J, Scheunemann P, Izbicki JR, Schneider C, Schumacher U, Witter K, Speicher MR, Pantel K: Malignant potential and cytogenetic characteristics of occult disseminated tumor cells in esophageal cancer. Cancer Res 2000, 60:6836-6840.

12. Zhong XY, Kaul S, Lin YS, Eichler A, Bastert G: Sensitive detection of micrometastases in bone marrow from patients with breast cancer using immunomagnetic isolation of tumor cells in combination with reverse transcriptase/polymerase chain reaction for cytokeratin-19. J Cancer Res Clin Oncol 2000, 126:212-218.

13. Flatmark K, Bjornland K, Johannessen HO, Hegstad E, Rosales R, Harklau L, Solhaug JH, Faye RS, Soreide O, Fodstad O: Immunomagnetic detection of micrometastatic cells in bone marrow of colorectal cancer patients. Clin Cancer Res 2002, 8:444-449.

14. Ree AH, Engerbraaten O, Hovig E, Fodstad O: Differential display analysis of breast carcinoma cells enriched by immunomagnetic target cell selection: gene expression profiles in bone marrow target cells. Int J Cancer 2002, 97:28-33.

15. Weihrauch MR, Skibowski E, Koslowsky TC, Voiss W, Re D, KuhnRegnier F, Bannwarth C, Siedek M, Diehl V, Bohlen H: Immunomagnetic enrichment and detection of micrometastases in colorectal cancer: correlation with established clinical parameters. J Clin Oncol 2002, 20:4338-4343.

16. Choesmel V, Anract $P$, Høifødt $H$, Thiery JP, Blin N: A relevant immunomagnetic assay to detect and characterize EpCAMpositive cells in bone marrow from breast cancer patients. Cancer 2004 in press.

17. Pierga JY, Bonneton $C$, Vincent-Salomon $A$, de Cremoux $P$, Nos $C$, Blin N, Pouillard P, Thiery JP, Magdelenat $\mathrm{H}$ : Clinical significance of immunocytochemical detection of tumor cells using digital microscopy in peripheral blood and bone marrow of breast cancer patients. Clin Cancer Res 2000, 10:1392-1400.

18. Cordell JL, Falini B, Erber WN, Ghosh AK, Abdulaziz Z, MacDonald $S$, Pulford KA, Stein H, Mason DY: Immunoenzymatic labeling of monoclonal antibodies using immune complexes of alkaline phosphatase and monoclonal anti-alkaline phosphatase (APAAP complexes). J Histochem Cytochem 1984, 32:21 9-229.

19. Singletary SE, Allred C, Ashley P, Bassett LW, Berry D, Bland KI, Borgen PI, Clark G, Edge SB, Hayes DF, Hughes LL, Hutter RV, 
Morrow M, Page DL, Recht A, Theriault RL, Thor A, Weaver DL, Wieand HS, Greene FL: Revision of the American Joint Committee on Cancer staging system for breast cancer. J Clin Oncol 2002, 20:3628-3636.

20. Rosenberg R, Gertler R, Friederichs J, Fuehrer K, Dahm M, Phelps R, Thorban S, Nekarda H, Siewert JR: Comparison of two density gradient centrifugation systems for the enrichment of disseminated tumor cells in blood. Cytometry 2002, 49:150-158.

21. Borgen E, Naume B, Nestland JM, Kvalheim G, Beiske K, Fodstad O, Diel IJ, Solomayer EF, Theocharous P, Coombes RC, Smith BM, Wunder E, Marolleau JP, Garcia J, Pantel K: Standardization of the immunocytochemical detection of cancer cells in BM and blood: I. establishment of objective criteria for the evaluation of immunostained cells. Cytotherapy 1999, 1:377-388.

22. Gerber B, Krause A, Muller H, Richter D, Reimer T, Makovitzky J, Herrning C, Jeschke U, Kundt G, Friese K: Simultaneous immunohistochemical detection of tumor cells in lymph nodes and bone marrow aspirates in breast cancer and its correlation with other prognostic factors. J Clin Oncol 2001, 19:960-971.

23. Bostick PJ, Chatterjee S, Chi DD, Huynh KT, Giuliano AE, Cote R, Hoon DS: Limitations of specific reverse-transcriptase polymerase chain reaction markers in the detection of metastases in the lymph nodes and blood of breast cancer patients. $J$ Clin Oncol 1998, 16:2632-2640.

24. Witzig TE, Bossy B, Kimlinger T, Roche PC, Ingle JN, Grant C, Donohue J, Suman VJ, Harrington D, Torre-Bueno J, Bauer KD: Detection of circulating cytokeratin-positive cells in the blood of breast cancer patients using immunomagnetic enrichment and digital microscopy. Clin Cancer Res 2002, 8:1085-1091.

25. Diel IJ, Kaufmann M, Costa SD, Holle R, von Minckwitz G, Solomayer EF, Kaul S, Bastert G: Micrometastatic breast cancer cells in bone marrow at primary surgery: prognostic value in comparison with nodal status. J Natl Cancer Inst 1996, 88:1652-1658.

26. Mansi JL, Gogas H, Bliss JM, Gazet JC, Berger U, Coombes RC: Outcome of primary-breast-cancer patients with micrometastases: a long-term follow-up study. Lancet 1999, 354:197-202.

27. Naume B, Borgen E, Kvalheim G, Karesen R, Qvist H, Sauer T, Kumar T, Nesland JM: Detection of isolated tumor cells in bone marrow in early-stage breast carcinoma patients: comparison with preoperative clinical parameters and primary tumor characteristics. Clin Cancer Res 2001, 7:4122-4129.

28. Gebauer G, Fehm T, Merkle E, Beck EP, Lang N, Jager W: Epithelial cells in bone marrow of breast cancer patients at time of primary surgery: clinical outcome during long-term follow-up. $J$ Clin Oncol 2001, 19:3669-3674.

29. Wiedswang G, Borgen E, Karesen R, Kvalheim G, Nesland JM, Schlichting HQE, Sauer T, Janbu J, Harbitz T, Naume B: Detection of isolated tumor cells in bone marrow is an independent prognostic factor in breast cancer. J Clin Oncol 2003, 21:3469-3478.

30. Thurm H, Ebel S, Kentenich $\mathrm{C}$, Hemsen A, Riethdorf S, Coith $\mathrm{C}$, Wallwiener D, Braun S, Oberhoff C, Janicke F, Pantel K: Rare expression of epithelial cell adhesion molecule on residual micrometastatic breast cancer cells after adjuvant chemotherapy. Clin Cancer Res 2003, 9:2598-2604.

31. Baker MK Mikhitarian K, Osta W, Callahan K, Hoda R, Brescia F, Kneuper-Hall R, Mitas M, Cole DJ, Gillanders WE: Molecular detection of breast cancer cells in the peripheral blood of advanced-stage breast cancer patients using multimarker real-time reverse transcription-polymerase chain reaction and a novel porous barrier density gradient centrifugation technology. Clin Cancer Res 2003, 9:4865-4871.

32. Borgen E, Beiske K, Trachsel S, Nesland JM, Kvalheim G, Herstad TK Schlichting $E$, Ovist $H$, Naume B: Immunocytochemical detection of isolated epithelial cells in bone marrow: non-specific staining and contribution by plasma cells directly reactive to alkaline phosphatase. J Pathol 1998, 185:427-434.

33. Braun S, Hepp F, Kentenich CR, Janni W, Pantel K, Riethmuller G, Willgeroth $\mathrm{F}$, Sommer HL: Monoclonal antibody therapy with edrecolomab in breast cancer patients: monitoring of elimination of disseminated cytokeratin-positive tumor cells in bone marrow. Clin Cancer Res 1999, 5:3999-4004.

34. Schroder CP, Ruiters MH, de Jong S, Tiebosch AT, Wesseling J, Veenstra R, de Vries J, Hoekstra HJ, de Leij LF, de Vries EG: Detection of micrometastatic breast cancer by means of real time quantitative RT-PCR and immunostaining in perioperative blood samples and sentinel nodes. Int J Cancer 2003, 106:611-618.

35. Packeisen J, Kaup-Franzen $\mathrm{C}$, Knieriem HJ: Detection of surface antigen 17-1A in breast and colorectal cancer. Hybridoma 1999, 18:37-40

36. Gastl G, Spizzo G, Obrist P, Dunser M, Mikuz G: Ep-CAM overexpression in breast cancer as a predictor of survival. Lancet 2000, 356:1981-1982.

37. Braun S, Hepp F, Sommer HL, Pantel K: Tumor-antigen heterogeneity of disseminated breast cancer cells: implications for immunotherapy of minimal residual disease. Int $J$ Cancer 1999, 84:1-5.

38. Litvinov SV, Velders MP, Bakker HA, Fleuren GJ, Warnaar SO: EpCAM: a human epithelial antigen is a homophilic cell-cell adhesion molecule. J Cell Biol 1994, 125:437-446.

39. Balzar M, Winter MJ, de Boer CJ, Litvinov SV: The biology of the 17-1A antigen (Ep-CAM). J Mol Med 1999, 77:699-712.

40. Jojovic M, Adam E, Zangemeister-Wittke U, Schumacher U: Epithelial glycoprotein-2 expression is subject to regulatory processes in epithelial-mesenchymal transitions during metastases: an investigation of human cancers transplanted into severe combined immunodeficient mice. Histochem $J$ 1998, 30:723-729.

41. Gires O, Kieu C, Fix P, Schmitt B, Munz M, Wollenberg B, Zeidler R: Tumor necrosis factor alpha negatively regulates the expression of the carcinoma-associated antigen epithelial cel adhesion molecule. Cancer 2001, 92:620-628.

42. Ferrero M, Spyratos F, Le Doussal V, Desplaces A, Rouesse J: Flow cytometric analysis of DNA content and keratins by using CK7, CK8, CK18, CK19, and KL1 monoclonal antibodies in benign and malignant human breast tumors. Cytometry 1990 11:716-724.

43. Franzen B, Linder S, Alaiya AA, Eriksson E, Uruy K, Hirano T, Okuzawa K, Auer G: Analysis of polypeptide expression in benign and malignant human breast lesions: down-regulation of cytokeratins. Br J Cancer 1996, 74:1632-1638.

44. Brotherick I, Robson CN, Browell DA, Shenfine J, White MD, Cunliffe WJ, Shenton BK, Egan M, Webb LA, Lunt LG, Young JR, Higgs MJ: Cytokeratin expression in breast cancer: phenotypic changes associated with disease progression. Cytometry 1998, 32:301-308

45. Su L, Morgan PR, Lane EB: Expression of cytokeratin messenger RNA versus protein in the normal mammary gland and in breast cancer. Hum Pathol 1996, 27:800-806. 